\title{
Diet of the Chilean flamingo Phoenicopterus chilensis (Phoenicopteriformes: Phoenicopteridae) in a coastal wetland in Chiloé, southern Chile
}

\author{
Claudio N Tobar ${ }^{1 *}$, Jaime R Rau², Norka Fuentes ${ }^{3}$, Alberto Gantz ${ }^{2}$, Cristián G Suazo ${ }^{4}$, Jaime A Cursach ${ }^{2,5}$, \\ Alexis Santibañez ${ }^{1}$ and Jorge Pérez-Schultheiss ${ }^{6}$
}

\begin{abstract}
Background: The geographical distribution of the Chilean flamingo (Phoenicopterus chilensis) includes the southern-central Neotropics. Despite its wide distribution, currently there is no dietary information on its southern distribution range. From June to September 2011, we quantified the diet and prey availability of the Chilean flamingo in the marine wetland of Caulín ( $41^{\circ} 48^{\prime}$ S, $73^{\circ} 37^{\prime}$ W), southern Chile.

Results: The prey availability related to both plankton and benthos were four species of copepods, four polychaetes, one foraminifera, and two amphipods. The diet of the Chilean flamingo was composed of foraminifera (Ammonia beccarii), copepods (Harpacticus sp.) and polychaetes. The most abundant prey items from feces of flamingos were Ammonia beccarii and Harpacticus sp. The diameter of A. beccarii consumed by flamingos ranged between 400 and $900 \mu \mathrm{m}$, while its width varied between 100 and $300 \mu \mathrm{m}$. The width of Harpacticus sp. consumed ranged between 160 and $260 \mu \mathrm{m}$. The similarity between flamingo diet and prey availability was 0.553 . The diversity of prey organisms in the benthos was higher than that observed from plankton and feces of birds. A. beccarii was preferred over other prey consumed by flamingos. This preference is not related to the size of Harpacticus sp. but to their ability to swim and escape from flamingos.

Conclusions: The dietary similarity of the Chilean flamingo versus the availability of prey in the environment (plankton and benthos) was 55\%, indicating that the Chilean flamingo is a partially selective predator.
\end{abstract}

Keywords: Copepods; Diet selectivity; Migration; Trophic ecology

\section{Background}

There are six species of flamingo in existence worldwide, and three of them are found in the Neotropical region. The most common species in this region is the Chilean flamingo Phoenicopterus chilensis (Molina 1782) (Brandolin and Ávalos 2010). Its range stretches from the center-south coasts of Peru and the south of Brazil to Patagonia (Hurlbert and Keith 1979; Fjeldsa and Krabbe 1990; Parada 1990; Rodríguez and Contreras 1998; Araya and Millie 2005). In Chile, this species is currently found from the Parinacota Province (ca. $\left.20^{\circ} \mathrm{S}\right)$ to Tierra del Fuego $\left(\mathrm{ca} .52{ }^{\circ} \mathrm{S}\right.$ ) (Araya and Millie 2005). With regard to the nesting habits of this bird in Chile, it only nests in the extreme North (Venegas 1986), while the populations found in the South nest in Argentinean Patagonia (Von Meyer and Espinosa 1998).

The ecological information published on this species makes reference to observations on certain reproductive aspects (Sosa 1999), geographical distribution and population fluctuations (Johnson et al. 1958; Caziani et al. 2001, 2007; Rocha 1997), nesting, habitat use (Mascitti 2001; Mascitti and Bonaventura 2002; Mascitti and Castañera 2006), and conservation status (Bucher 1992). If we consider its widespread population distribution throughout the country, there are currently no existing publications about the Chilean flamingo's diet nor do we know the prey selection strategy (selective or opportunistic) it uses in the different environments in which it lives. The study carried out by Mascitti and Kravetz (2002) on the Chilean flamingo

Departamento de Ciencias Básicas, Universidad Santo Tomás, Los Carrera

753, 5310431, Osorno, Chile

Full list of author information is available at the end of the article

\section{Springer}

(C) 2014 Tobar et al.; licensee Springer. This is an Open Access article distributed under the terms of the Creative Commons Attribution License (http://creativecommons.org/licenses/by/2.0), which permits unrestricted use, distribution, and reproduction in any medium, provided the original work is properly credited. 
and the Andean flamingo (Phoenicoparrus andinus Philippi 1854) and James's flamingo (Phoenicopterus jamesi, Sclater 1886) in the Argentinean Andean Plateau do indicates, however, that these species select their prey based on size due to a distinctive characteristic of their beaks, which contain small ridges to capture food when filtering the substrate. Other authors describe the Chilean flamingo as an omnivorous bird that feeds principally on diatoms, nematodes, and planktonic crustaceans (Hurlbert 1982; Hurlbert et al. 1986; Rodríguez 2005). According to the records of Von Meyer and Espinosa (1998), the Chilean flamingo keeps to the intertidal flats of Chiloé's island called Isla Grande to feed for most of the year except in summer. The presence of this species in the south of Chile and specifically in Chiloé could be related to its migratory routes as it moves towards Argentinean Patagonia in the spring and summer in search of nesting sites (Markham 1975; Von Meyer and Espinosa 1998). Its presence on the coast of the central and southern regions of Chile is largely associated with estuarial areas, which could be related to the higher quantity of food available in this kind of habitat during the winter season, as is the case with other migratory birds (Muñoz 1994; Cifuentes 2007). The protected coastal areas of the Chiloé Ecoregion and the Patagonian waterways in the south of Chile (ca. $42^{\circ}$ to $43^{\circ} \mathrm{S}$ ) provide a combination of nutritional resources and rest areas for resident and migratory birds. They are one of the main wintering sites in the south of the American continent for various species of coastal bird. This results from a combination of the area's oceanographic productivity and its topography (Morrison and Ross 1989). These protected intertidal areas contain high concentrations of phytoplankton (Avaria et al. 1997), which allow macrobenthic communities to be sustained (Quijón and Jaramillo 1993). These macrobenthic communities display seasonal variations in the abundance of benthic organisms. On the other hand, in spite of the high diversity of resident and migratory aquatic birds that live in Caulín Bay, there is in fact no existing information on prey availability in the benthos of the bay's intertidal zone (Cifuentes 2007).

As a result, the objectives of this study were to present the first quantifiable information on the diet of the Chilean flamingo, to quantify potential prey profile availability (zooplankton and benthos), and to determine the size of prey consumed in a marine wetland on the Isla Grande island in Chiloé, southern Chile. Our hypothesis was as follows: The Chilean flamingo will not show evidence of dietary selection and will consume the prey present in Caulín Bay opportunistically.

\section{Methods}

\section{Study area}

Visits to Caulín Bay were carried out over three consecutive days between the months of June and September
2011. Sampling days coincided with the lowest tides, allowing for a greater surface area for sample collection. Potential prey profile availability was quantified, and their feces were collected for diet evaluation. The Caulín Bay $\left(41^{\circ} 49^{\prime} \mathrm{S}, 73^{\circ} 38^{\prime} \mathrm{W}\right)$ bird sanctuary is found in the northern zone of Chiloé's Isla Grande Island, southern Chile (Figure 1). The sand flat features an annual average tide height of around $4.5 \mathrm{~m}$ at spring tide and $3 \mathrm{~m}$ at neap tide (Cifuentes 2007). The intertidal strip is approximately $600 \mathrm{~m}$ at spring tide (Cifuentes 2007). The River Huenque runs through the middle of the sand flat, dividing it into two sectors. The eastern sector is primarily muddy, while the western sector is primarily sandy (Cifuentes 2007). The intertidal zone of Caulín Bay is subject to the constant harvesting of sea products, especially the collection and cultivation of pelillo seaweed (Gracilaria chilensis Bird, McLachlan and Oliveira 1986) and Bluff oyster (Ostrea chilensis Philippi 1845).

\section{Sampling methodology}

The Chilean flamingo's available food and the variation of that food over the different months were characterized. Samples of plankton were taken at the feeding sites and the control sites. The feeding sites were located in the intertidal zone of Caulín Bay and were chosen based on observation of the bioperturbations left by the Chilean flamingo during feeding. The bioperturbation is known as a 'feeding ring', and it is produced by the birds' feet churning up the benthos as it swivels on its axis and uses its body as a pivot. It filters the suspended sediment with its beak and then deposits the filtered sediment in the center of the ring (Cifuentes 2007). In order to sample the zooplankton, horizontal sweeps of 800-m transects were made perpendicular to the tideline. To avoid stirring up sediment in the Chilean flamingo's feeding sites, these were undertaken as discreet walks using conical plankton nets (net mouth area $0.3 \mathrm{~m}$ diameter by $1.2 \mathrm{~m}$ in length), with a mesh size of $150 \mu \mathrm{m}$, to obtain a total of 12 samples.

The taxonomic analysis was carried out in the laboratory with a stereoscopic microscope $(\times 10$ to $\times 30)$ and an optical microscope $(\mathrm{OM})$ with $\times 400$ magnification. Taxonomic guides (Araya and Zúñiga 1985; Goddard and Zúñiga 1995) and OM photographs of the different taxa were used to identify the prey. The OM photographs were taken with the aid of a photographic camera (Sony DSC-HX200V, Sony Corporation, Tokyo, Japan) incorporated into the microscope. Once the samples were classified, the frequency that each prey animal appeared was determined. In turn, the abundance and size of each prey animal were recorded for the most frequent prey animals. To record the abundance of the most frequent zooplankton prey, a count was carried out using transects according to the method proposed by Villafañe and Reid (1995). 


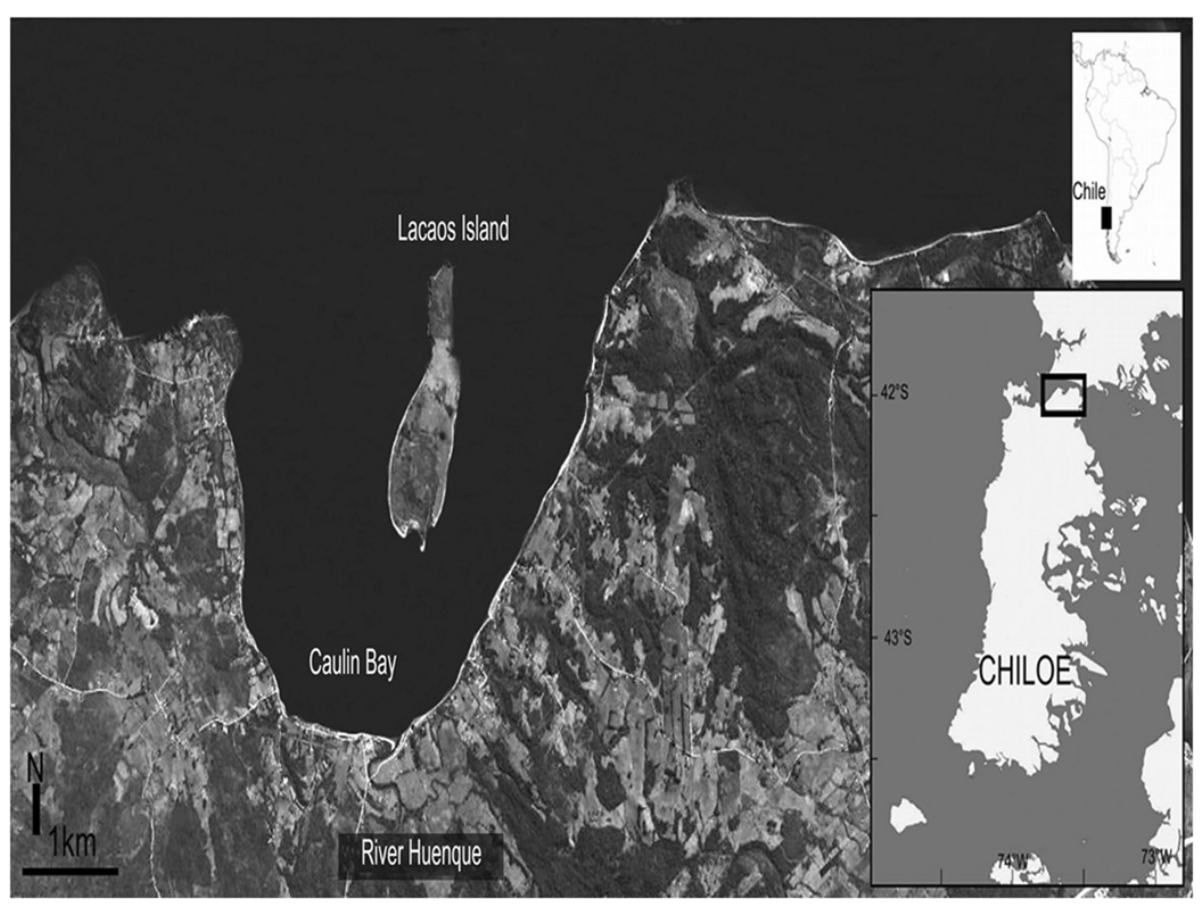

Figure 1 Study area. The intertidal sand flat of Caulín Bay $\left(41^{\circ} 49^{\prime} \mathrm{S}, 73^{\circ} 38^{\prime} \mathrm{W}\right.$ ), Chiloe Island, southern Chile.

The Sedgwick-Rafter camera was replaced by a microscope slide and a slide cover of $32 \times 25 \mathrm{~mm}$. A $0.05-\mathrm{ml}$ portion was deposited on the slide, and three equidistant horizontal transects were taken avoiding border effects (Fabricius et al. 2005). To obtain the abundance of prey animals per sample, the average of three counts for each of the samples was taken. To measure the most frequent species, LAS Versión 1.5 software incorporated into a Leica EZ microscope (Leica Microsystems Ltd., Milton Keynes, UK) was used.

During the study period, the monthly sampling of macroinvertebrates present in the benthos was taken during the spring tide (Cifuentes 2007). Six random samples were taken from the first $10 \mathrm{~cm}$ in depth (three at the Chilean flamingo's feeding area and three at control sites). A corer with a 7-cm diameter was used for this purpose. The samples were studied under a stereoscopic microscope and an $\mathrm{OM}$, and the organisms identified using taxonomic guides (Rozbaczylo 1980; Jaramillo 1982) were preserved in 10\% formalin so that the specimens could later be quantified. To obtain the abundance of prey animals per sample, the average of three counts for each of the samples was taken. To measure the most frequent species, LAS Versión 1.5 software incorporated into a Leica EZ microscope was used.

The diet of the Chilean flamingo was evaluated by means of the analysis of a total of 77 feces that were collected during low tide in feeding sites used by the birds. Each feces corresponded to the deposit of an individual adult, which were classified as belonging to this age group via observation of its plumage using a microscope $(\times 60)$ during the feeding and subsequent defecation process. The feces were collected once the birds had left the feeding sites. They were subsequently dried at ambient temperature and then processed in the laboratory. The feces were studied under a stereoscopic microscope and OM, and the organisms were identified using taxonomic guides and were preserved in $10 \%$ formalin so that the specimens could later be quantified. To quantify and measure the size of the most frequent prey animals (crustaceans and foraminifera) in the feces of the Chilean flamingo, the same methodology was used as for the quantification of available prey. To quantify the polychaetes, one individual corresponded to one pair of jaws since the rest of the polychaete was digested.

\section{Statistical analysis}

The similarity of the species present in the environment (plankton and benthos) versus those present in the feces was estimated using Horn's quantitative index of overlap (Rau 2009) and the QUANTAN computational program (Brower et al. 1997). The taxonomic diversity present in the environment and the diversity of prey in the Chilean flamingo's diet were determined using the Shannon-Wiener $\left(H^{\prime}\right)$ index and the (Franja 1993) program. The Hutcheson test was used to compare the Chilean flamingo's dietary diversity and potential prey profile availability. This allowed for a comparison of the $H^{\prime}$ diversity and its associated analytical variances using a test analogous to Student's $t$ test (see Moreno 2001). To 
compare the differences in the frequency of occurrence of the Chilean flamingo's most consumed prey with the frequency of occurrence for the prey present in the feeding sites during the different study months, an $\chi^{2} y$ test was used, and in the event that it was significant, Bonferroni simultaneous confidence intervals (BSCI) were formed. A $x^{2} y$ test was also used in order to compare the difference in frequency of the sizes of prey consumed by the Chilean flamingo, and in the event that it was significant, BSCI were used. BSCI are ranges of statistical probability that are used in multiple paired comparisons. They have been used to calculate the selection of resources, such as prey and feeding sites (Suazo et al. 2012), since they allow one to establish the significance that an expected probability per category will fall within, or outside of, the interval constructed for the observed probability (Neu et al. 1974; Byers et al. 1984). To compare the monthly differences for the most abundant species of zooplankton in the water column, as well as macroinvertebrates present in the benthos at the feeding sites used by the Chilean flamingo during the study months, the nonparametric Kruskal-Wallis test was used with a significance level of $95 \%$. The online statistical package (http://vassarstats. net/) was used for all statistical analysis.

\section{Results}

\section{Prey availability}

Four species of copepod were identified in the water column in the feeding sites used by the Chilean flamingo. Of these, three were described at the level of the genus and one at the level of the order. The most abundant copepod during this study was Harpacticus sp. (Table 1). No significant differences were recorded in the availability of zooplankton during the study months (Kruskal-Wallis test $\left.H_{4}=23.138 ; P=0.336\right)$.

A total of seven species of organism present in the benthos were identified: four polychaetes, a foraminifera, and two amphipods. The most abundant species both in the feeding sites and in the control sites during the study period was the polychaete Perinereis gualpensis (Jeldes 1963) (Table 1). No significant differences were recorded in the availability of organisms in the benthos during the study months (Kruskal-Wallis test $H_{4}=0.666$; $P=0.881)$.

\section{Dietary analysis}

A total of three prey categories were identified; the foraminifera Ammonia beccarii Linné 1758, the copepod Harpacticus sp., and the remains of polychaetes (jaws). No frustules nor diatoms were observed. The most abundant preys in the feces of the Chilean flamingo were A. beccarii and Harpacticus sp. (Table 2). The diameter of the foraminifera consumed by the flamingo ranged from 400 to $900 \mu \mathrm{m}$ with a positive selection (preference) for organisms within the range of 500 to $700 \mu \mathrm{m}\left(\chi^{2}=132.104\right.$, g.l. $\left.=5, P=0.0001\right)$. The width of the foraminifera ranged between 100 and $300 \mu \mathrm{m}$, with a positive selection for organisms within the range of 200 to $300 \mu \mathrm{m}\left(\chi^{2}=32.649\right.$, g.l. $\left.=2, P=0.0001\right)$ (Figure 2). The width of Harpacticus sp. consumed by the Chilean

Table 1 Monthly variation (mean \pm SD) of planktonic and benthic organisms

\begin{tabular}{|c|c|c|c|c|}
\hline Species & June & July & August & September \\
\hline \multicolumn{5}{|l|}{ Plankton } \\
\hline \multicolumn{5}{|l|}{ Copepods } \\
\hline Harpacticus sp. & $40 \pm 85$ & $14 \pm 11$ & $24 \pm 17$ & $17 \pm 25$ \\
\hline Halicyclops sp. & $4 \pm 3$ & $2 \pm 3$ & $4 \pm 4$ & $6 \pm 8$ \\
\hline Dactylopusia sp. & $6 \pm 4$ & $1 \pm 1$ & - & $3 \pm 4$ \\
\hline Cyclopoida & $1 \pm 2$ & - & - & - \\
\hline Benthos & $\mathrm{a} / \mathrm{c}$ & $\mathrm{a} / \mathrm{c}$ & $a / c$ & $a / c$ \\
\hline \multicolumn{5}{|l|}{ Polychaetes } \\
\hline Nereididae & $6 \pm 7 / 6 \pm 3$ & - & - & - \\
\hline Perinereis gualpensis & $17 \pm 15 / 16 \pm 15$ & $29 \pm 14 / 42 \pm 12$ & $23 \pm 24 / 27 \pm 21$ & - \\
\hline Boccardia sp. & - & $5 \pm 1 / 7 \pm 4$ & $6 \pm 5 / 10 \pm 8$ & - \\
\hline Polychaete sp. & - & - & $1 \pm 2 / 1 \pm 1$ & $36 \pm 43 / 7 \pm 10$ \\
\hline \multicolumn{5}{|l|}{ Foraminifers } \\
\hline Ammonia beccarii & $3 \pm 1 / 6 \pm 7$ & - & $1 \pm 2 / 1 \pm 2$ & - \\
\hline \multicolumn{5}{|l|}{ Amphipods } \\
\hline Corophium insidiosum & $8 \pm 14 / 8 \pm 13$ & - & $1 \pm 1 / 1 \pm 1$ & - \\
\hline Heterophoxus sp. & $1 \pm 2 / 1 \pm 1$ & - & - & - \\
\hline
\end{tabular}

The organisms were present at (a) foraging sites used by the Chilean flamingo and (c) control sites in Caulín Bay. 
Table 2 Prey abundance $\left(\right.$ Ind $^{*} \mathrm{ml}^{-1}$ ) observed in the feces of the Chilean flamingo

\begin{tabular}{lc}
\hline Species & Ind $^{*} \mathbf{m l}^{\mathbf{- 1}}$ \\
\hline Polychaetes & 87 \\
Harpacticus sp. & 992 \\
Ammonia beccarii & 2,370 \\
\hline
\end{tabular}

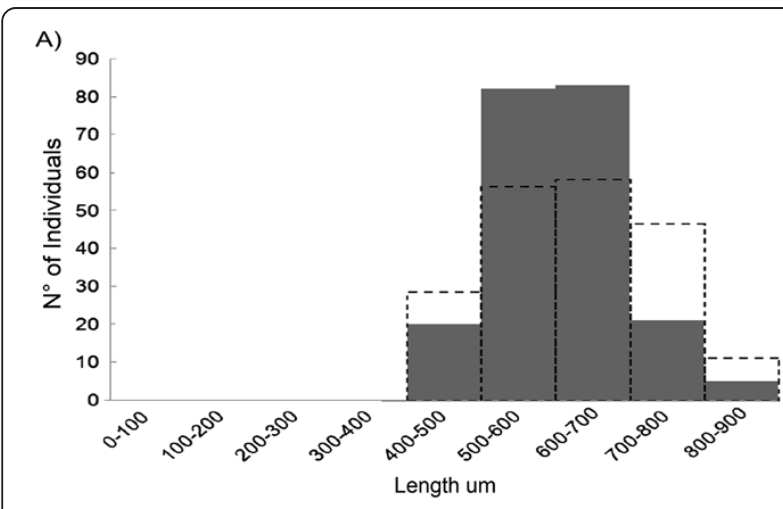

B)

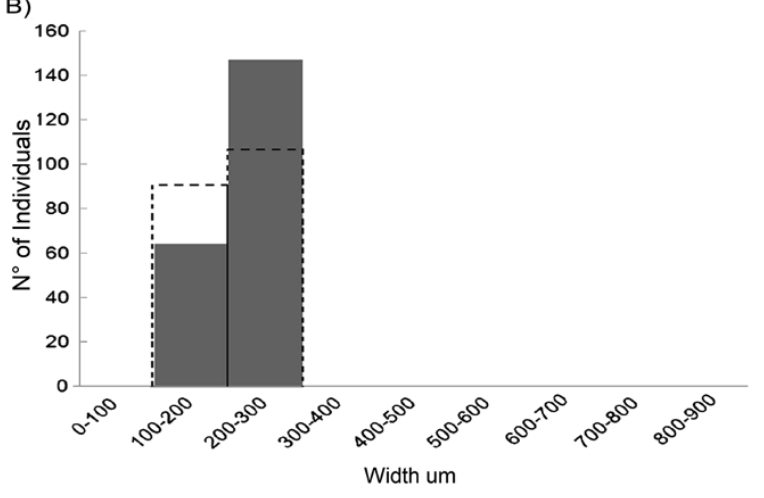

C)

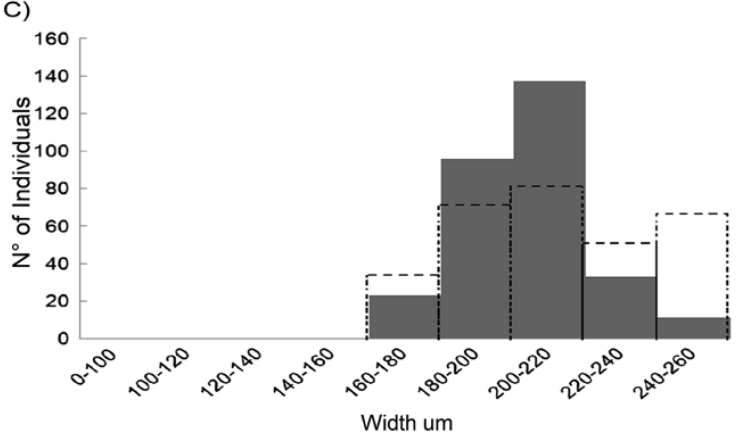

Figure 2 Size distribution of most abundant prey and prey size. Size distribution of the most abundant prey from feces of Chilean flamingos (dark columns) and most abundant prey size at foraging sites used by Chilean flamingos (segmented columns): (A) diameter of the foraminifera Ammonia beccarii, (B) body width of A. beccarii, and (C) body width of copepod Harpacticus sp.
Table 3 Diversity of preys $\left(H^{\prime} \pm S^{2}\right)$ in different types of substratum and in feces of the Chilean flamingo

\begin{tabular}{lc}
\hline Type of substrate & Trophic diversity $\left(\boldsymbol{H}^{\prime}\right)$ \\
\hline Benthos & $1.35 \pm 0.01999$ \\
Zooplankton & $0.706 \pm 0.0065$ \\
Feces & $0.717 \pm 0.00355$ \\
\hline
\end{tabular}

flamingo ranged between 160 and $260 \mu \mathrm{m}$ with a positive selection for organisms within the range of 180 to $220 \mu \mathrm{m}\left(\chi^{2}=195.400\right.$, g.l. $\left.=5, P=0.0001\right)$ (Figure 2).

The dietary similarity of the Chilean flamingo versus the availability of prey in the environment (plankton and benthos) was 0.553 . The diversity of prey present in the benthos was greater than that which was observed for the zooplankton and that which was present in the feces of the Chilean flamingo (Table 3). On comparing the diversity of prey present in the environment and in the feces, significant differences were only found for the paired comparison of the prey present in the benthos (Hutcheson $t$ test $=4.032 ; P<0.05$ ).

With regard to the frequency of occurrence in all of the feces, the foraminifera $(A$. beccarii) was observed to prevail over the rest $\left(\chi^{2}=4973.52\right.$, g.l. $\left.=6, P=0.0001\right)$. According to the Bonferroni simultaneous confidence intervals (BSCI), the prey item A. beccarii was consumed above the level expected by chance, and therefore, it was positively selected by the Chilean flamingo. Meanwhile, the Harpacticus sp. and the polychaetes were negatively selected (rejected) since they were consumed at levels lower than those expected by chance (Table 4).

\section{Discussion}

The diet of the Chilean flamingo is considered omnivorous, since it feeds both on phytoplankton (i.e., diatoms) and on zooplankton (i.e., copepods, brachiopods) (Rodríguez 2005). However, according to the information presented in this study, the diet of the Chilean flamingo in Caulín Bay was carnivorous and its trophic spectrum was made up of three kinds of invertebrate prey just as has been recorded by other authors in lagoons that this flamingo uses for feeding in the Andean Plateau (Hurlbert 1982; Hurlbert et al. 1984,

Table 4 Prey selection of the Chilean flamingo in the study area from June to September 2011

\begin{tabular}{lccc}
\hline Prey & $\boldsymbol{P}$ observed & $\boldsymbol{P}$ expected & Bonferroni intervals \\
\hline Harpacticus sp. & 0.287 & 0.840 & $0.183 \leq P_{1} \leq 0.391^{*}(-)$ \\
Polychaetes & 0.028 & 0.150 & $0.000 \leq P_{2} \leq 0.066^{*}(-)$ \\
Ammonia beccarii & 0.685 & 0.010 & $0.578 \leq P_{3} \leq 0.792^{*}(+)$ \\
\hline
\end{tabular}

Bonferroni's simultaneous confidence intervals were applied to assess observed versus expected proportion of consumed prey. *Statistically significant differences $P<0.05(-)$ corresponded to prey items consumed less than expected by chance, and $(+)$ consumed in greater proportion than expected by chance. $X^{2}=4973.52 ; P=0.0001$. 
1986). In spite of the fact that diatoms were observed in the areas used by the Chilean flamingo for feeding, no diatom frustules were seen in the feces. The absence of diatom frustules in the diet of the Chilean flamingo may be due to the smaller size of these organisms (CN Tobar, pers. observ. 2011), which are not caught by the filtering ridges found in the Chilean flamingo's beak (Mascitti and Kravetz 2002). When the Chilean flamingo's beak is closed, this functional sieve has at least $80 \mu \mathrm{m}$ between the side ridges of the proximal part of the beak and spaces of no more than $959 \mu \mathrm{m}$ in the curved and distal parts (Mascitti and Kravetz 2002). The diatoms found in the marine wetlands of Caulín Bay are between 20 and $105 \mu \mathrm{m}$ in size, smaller than the diatoms found in the Chilean Altiplano Lakes (between 58 and $140 \mu \mathrm{m})$, which are the main food of the Andean flamingo (Phoenicoparrus andinus Philippi 1854) (Tobar et al. 2012). The information contributed by Mascitti and Kravetz (2002) on the diet of the three flamingo species suggests that the filters found in their beaks create differences in the size of prey selected by each of these birds.

The potential prey profile availability with regard to zooplankton was represented by just four species while eight were recorded in the benthos. For the more abundant species both in the zooplankton and in the benthos, variations in abundance were recorded throughout the different sampling months.

With regard to the prey consumed most frequently by the Chilean flamingo, the foraminifera $A$. beccarii and the copepod Harpacticus sp. stood out. The size of both the diameter and the width of the foraminifera and the width of the copepod are consistent with the size of organisms $(>100 \mu \mathrm{m})$ consumed by this flamingo in the lagoons found in the Argentinean Andean Plateau (Mascitti and Kravetz 2002). The dietary similarity of the Chilean flamingo versus the availability of prey in the environment (plankton and benthos) was 55\%, indicating that the Chilean flamingo is a partially selective predator. The Chilean flamingo's prey selection is not governed by the nutritional elements provided by the prey consumed, but rather by the morphostructural restrictions of the bird's beak. With regard to the flamingo's positive selection for $A$. beccarii ahead of Harpacticus sp., this is not related to its size, but rather to the prey's escape behavior, due to the swimming capabilities that copepods use to avoid falling prey to the Chilean flamingo (Hurlbert 1982).

\section{Conclusion}

The diet of the Chilean flamingo in Caulín Bay was carnivorous and its trophic spectrum was made up of only three kinds of invertebrate prey. The potential prey profile availability with regard to zooplankton was represented by just four species while eight were recorded in the benthos. For the more abundant species both in the zooplankton and in the benthos, variations in abundance were recorded throughout the different sampling months. The prey consumed most frequently by the Chilean flamingo, the foraminifera Ammonia beccarii and the copepod Harpacticus sp. stood out. The size of both the diameter and the width of the foraminifera and the width of the copepod are consistent with the size of organisms $(>100 \mu \mathrm{m})$. The dietary similarity of the Chilean flamingo versus the availability of prey in the environment (plankton and benthos) was 55\%, indicating that the Chilean flamingo is a partially selective predator.

\section{Competing interests}

The authors declare that they have no competing interests.

\section{Authors' contributions}

CNT, JAC, AS conceived the study and participated in its design and coordination. JRR, NF, AG participated in the design of the study and performed the statistical analysis. JPS participates in the taxonomic identification. All authors read and approved the final manuscript.

\section{Acknowledgements}

The authors thank Dr. Gonzalo Gajardo for making the physical space and the microscopic equipment of the Laboratory of Genetics, Aquaculture and Biodiversity of the University of Los Lagos available, and Patricia Beristain, Margarita Parraguez, Jonnathan Vilugrón, and Mauricio Martínez for providing materials and for their important comments in the development of this research. The first author (CNT) would like to thank Ramón Molina and family (Ostras Caulín) for their logistical support and imparting their knowledge on the birds found in Caulín; to Christopher Anderson, Martin Thiel, and Diego Meier for corrections to the manuscript; and finally to the BIODES Research Center of the University of Los Lagos for officially financing this research.

\section{Author details}

'Departamento de Ciencias Básicas, Universidad Santo Tomás, Los Carrera 753, 5310431, Osorno, Chile. 'Laboratorio de Ecología, Depto de Ciencias Biológicas y Biodiversidad \& Programa IBAM, Universidad de Los Lagos, Casilla 933, 5310887, Osorno, Chile. ${ }^{3}$ Departamento de Acuicultura y Recursos Agroalimentarios, Universidad de Los Lagos, Casilla 933, 5310887, Osorno, Chile. ${ }^{4}$ Department of Animal Ecology and Systematics, Justus Liebig University Giessen, Heinrich-Buff-Ring 38, 35392, Giessen, Germany. ${ }^{5}$ Programa de Doctorado en Ciencias mención Conservación y Manejo de Recursos Naturales, Universidad de Los Lagos, Casilla 557, 5310887, Puerto Montt, Chile. ${ }^{6}$ Centro de Estudios en Biodiversidad (CEBCh), Magallanes 1979, 5312498, Osorno, Chile.

Received: 13 June 2013 Accepted: 30 June 2014

Published online: 16 August 2014

\section{References}

Araya JM, Zúñiga LR (1985) Manual taxonómico del zooplancton lacustre de Chile. Boletín Limnológico, Universidad Austral de Chile 8:1-169

Araya BM, Millie GH (2005) Guía de campo de las aves de Chile, 10th edn. Ed. Universitaria, Chile

Avaria S, Cassis D, Muñoz P, Vera P (1997) Distribución del microfitoplancton marino en aguas interiores del sur de Chile en octubre de 1995 (Crucero Cimar-Fiordo 1). Ciencia y Tecnología del Mar 20:107-123

Brandolin G, Ávalos M (2010) Nuevos registros estivales de flamenco andino Phoenicoparrus andinus para la llanura central de Argentina, Provincia de Córdoba. Cotinga 32:5-7

Brower J, Zar J, Von ende C (1997) Field and laboratory methods for general ecology, 4th edn. Wm C. Brown Publishers, Dubuque, lowa

Bucher E (1992) Population and conservation status of flamingos in Mar Chiquita, Cordoba, Argentina. Colonial Waterbirds 15:179-184

Byers CR, Steinhorst RK, Krausman PR (1984) Clarification of a technique for analysis of utilization-availability data. Journal of Wildlife Management 48:1050-1053 
Caziani SM, Derlindati EJ, Tálamo A, Sureda AL, Trucco CE, Nicolossi G (2001) Waterbird richness in altiplano wetlands of northwestern Argentina. Waterbirds 24:103-117

Caziani SM, Rocha O, Rodríguez E, Romano M, Derlindati EJ, Tálamo A, Ricalde D, Quiroga C, Contreras JP, Valqui M, Sosa H (2007) Seasonal distribution, abundance, and nesting of Puna, Andean, and Chilean flamingos. Condor 109:276-287

Cifuentes S (2007) Efecto de la depredación/bioperturbación del flamenco chileno Phoenicopterus chilensis (Molina 1782) (Phoenicopteridea; Ciconiiformes) y la variabilidad espacio-temporal del macrobentos en una planicie intermareal de la Isla Grande de Chiloé, sur de Chile. Tesis para optar al grado de Doctor en Ciencias. Facultad de Ciencias. Universidad Austral de Chile, Valdivia

Fabricius AL, Luque ME, Bocolini M (2005) Diatomeas planctónicas de cursos de agua. Cuenca del Río Piedra Blanca (Córdoba, Argentina). Boletín de la Sociedad Argentina de Botánica 40:183-198

Franja (1993) Programa Índice de Diversidad (DIVERS.EXE) y Medidas de Similitud (SIMIL.EXE). Disponible en: Granada, España. http://www.perso.wanadoo.es/ Jp-L/descargas.htm

Fjeldsa J, Krabbe N (1990) Birds of the high Andes. Apollo Books, Svendborg, Denmark

Goddard M, Zúñiga L (1995) Copépodos de pozas intermareales de Montemar,

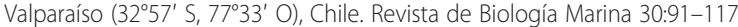

Hurlbert S, Keith JO (1979) Distribution and spatial patterning of flamingos in the Andean Altiplano. Auk 96:328-342

Hurlbert S (1982) Limnological studies of flamingo diets and distributions. Res Rep Natl Geogr Soc 14:351-356

Hurlbert S, López M, Keith J (1984) Wilson's phalarope in the Central Andes and its interaction with the Chilean flamingo. Revista Chilena de Historia Natura $57: 47-57$

Hurlbert S, Loayza W, Moreno T (1986) Fish-flamingo-plankton interaction in the Peruvian Andes. Limnol Oceanogr 30:457-468

Jaramillo E (1982) Taxonomy, natural history and zoogeography of sand beach isopods from the coast of southern Chile. Stud Neotrop Fauna E 17:175-194

Johnson AW, Behn F, Millie W (1958) The South American flamingos. Condor 60:289-299

Markham B (1975) Censo invernal de cisnes y flamencos en Magallanes. Anales del Instituto de la Patagonia (Chile) 1:146-157

Mascitti V (2001) Habitat changes in laguna de Pozuelos, Jujuy, Argentina: implications for South American flamingo populations. Waterbirds 24:16-2

Mascitti V, Bonaventura S (2002) Patterns of abundance, distribution and habitat use of flamingos in the high Andes, South America. Waterbirds 25:358-365

Mascitti V, Kravetz FO (2002) Bill morphology of South American flamingos. Condor 104:73-83

Mascitti V, Castañera M (2006) Foraging depth of flamingos in single-species and mixed-species flocks at Laguna de Pozuelos, Argentina. Waterbirds 29:328-334

Moreno CE (2001) Métodos para Medir La Biodiversidad. M \& T- Manuales y Tesis SEA. Vol. 1. Editores CYTED (Programa Iberoamericano de Ciencia y Tecnología para el Desarrollo), ORCYT - UNESCO (Oficina Regional de Ciencia y Tecnología para América Latina y el Caribe, Sociedad Entomológica Aragonesa (SEA), Zaragoza. 84pp

Morrison R, Ross R (1989) Atlas of Neartic shorebirds on the coast of South America. Vol. 1 \& 2. Canadian Wildlife Service Special Publication, Ottawa

Muñoz M (1994) Usos del recurso espacio por las aves costeras que habitan la planicie intermareal del estuario del río Queule, IX Región, Centro-sur de Chile. Tesis de grado M.Sc., mención Zoología. Facultad de Ciencias. Universidad Austral de Chile, Valdivia

Neu CW, Byers CR, Peek JM (1974) A technique for analysis of utilizationavailability data. J Wildl Manag 38:541-545

Parada M (1990) Flamencos en el norte de Chile. Distribución, abundancia y fluctuaciones estacionales del número. In: Parada M, Rottmann J, Guerra C (eds) I Taller Internacional de Especialistas en Flamencos Sudamericanos: Corporación Nacional Forestal-Chile y New York Zoological Society

Quijón P, Jaramillo E (1993) Temporal variability in the intertidal macroinfauna in the Queule river estuary south-central Chile. Estuar Coast Shelf Sci 37:655-667

Rau JR (2009) Métodos de análisis en ecología trófica. In: Muñoz-Pedreros A Yáñez-Valenzuela J (eds) Mamíferos de Chile, 2ath edn. CEA Ediciones, Valdivia
Rocha O (1997) Fluctuaciones poblacionales de tres especies de flamencos en Laguna Colorada. Revista Boliviana de Ecología 2:67-76

Rodríguez E, Contreras JP (1998) Conservación de Flamencos en el Norte de Chile. In: Valverde V (ed) La Conservación de la Fauna Nativa de Chile. Logros y Perspectivas. Corporación Nacional Forestal, Santiago

Rodríguez E (2005) Flamencos altoandinos Phoenicopterus andinus (Philippi 1854), Phoenicopterus jamesi (Sclater 1886) y Phoenicopterus chilensis (Molina 1782), en el Norte de Chile: Estado actual y plan de conservación. Corporación Nacional Forestal, Antofagasta

Rozbaczylo N (1980) Clave para el reconocimiento de familias de anélidos poliquetos del mar chileno. Stud Neotrop Fauna E 15:167-196

Sosa H (1999) Descripción del evento reproductivo del flamenco austral (Phoenicopterus chilensis) en laguna Llancanelo, Malargüe, Mendoza. Multequina 8:87-99

Suazo CG, Arriagada AM, Rau JR (2012) Ephemeral aquatic bird assemblages in estuarine wetlands from South-Central Chile: using an intertidal flat habitat during the austral summer. Estuar Coast 35:1137-1143

Tobar C, Rau JR, Iriarte A, Villalobos R, Lagos N, Cursach J, Díaz C, Fuentes N, Gantz A (2012) Composition, diversity and size of diatoms consumed by the Andean Flamingo (Phoenicoparrus andinus) in salar de Punta Negra, Antofagasta Region, northern Chile. Ornitología Neotropical 23:243-250

Venegas C (1986) Aves de Patagonia y Tierra del Fuego Chileno Argentino. Ediciones de la Universidad de Magallanes, Punta Arenas

Villafañe VE, Reid FM (1995) Métodos de Microscopia para la Cuantificación del Fitoplancton. In: Alveal K, Ferrario ME, Oliveira EC, Sar E (eds) Manual de Métodos Ficológicos. Universidad de Concepción, Concepción

Von Meyer A, Espinosa L (1998) Situación del flamenco chileno (Phoenicopterus chilensis) en Chiloé y sur de la Provincia de Llanquihue. Boletín Chileno de Ornitología 5:16-20

doi:10.1186/s40693-014-0015-1

Cite this article as: Tobar et al:: Diet of the Chilean flamingo

Phoenicopterus chilensis (Phoenicopteriformes: Phoenicopteridae) in a coastal wetland in Chiloé, southern Chile. Revista Chilena de Historia Natural 2014 87:15.

\section{Submit your manuscript to a SpringerOpen ${ }^{\circ}$ journal and benefit from:}

- Convenient online submission

- Rigorous peer review

- Immediate publication on acceptance

- Open access: articles freely available online

- High visibility within the field

- Retaining the copyright to your article

Submit your next manuscript at $>$ springeropen.com 